\title{
Influence of Magnesium Deficiency on Induction of Activity of Antioxidative Enzymes and Increased Tolerance to Active Oxygen-Generating Herbicides in Cucumber and Kidney Bean Plants*
}

\author{
Jeung Joo Lee**, Byeng Chul Kim**, Hiroshi Matsumoto*** and Kenji Usui***
}

\begin{abstract}
The influence of a deficient $(7 \mu \mathrm{M})$ or sufficient $(1000 \mu \mathrm{M})$ supply of magnesium $\left(\mathrm{Mg}^{2+}\right)$ on the content of $\mathrm{Mg}^{2+}$, chlorophyll and protein, and the activity of superoxide dismutase (SOD), ascorbate peroxidase (AP) and glutathione reductase (GR) were studied in cucumber (Cucumis sativus L.) and kidney bean (Phaseolus vulgaris L.) plants over an 11-day period. Tolerance of kidney bean to paraquat and oxyfluorfen dependent injury were also determined with intact primary leaves. $\mathrm{Mg}^{2+}$ content in the primary leaves of cucumber and kidney bean plants grown in nutrient solution with sufficient $\mathrm{Mg}^{2+}$ supply was increased, while that in the leaves of plants grown with insufficient $\mathrm{Mg}^{2+}$ was very low. $\mathrm{Mg}^{2+}$ deficiency caused more severe chlorosis and protein reduction in cucumber than in kidney bean. The activities of AP, GR and SOD of $\mathrm{Mg}^{2+}$-deficient cucumber leaves were greatly enhanced compared to those of $\mathrm{Mg}^{2+}$-sufficient leaves. In $\mathrm{Mg}^{2+}$-deficient kidney bean leaves, AP and SOD activities were enhanced,
\end{abstract}

* This paper was supported by NON DIRECTED RESEARCH FUND, Korea Research Foundation, 1996.

** Dept. of Agricultural Biology, College of Agriculture, Gyeongsang National Univ., Chinju 660-701, Korea

*** Institute of Applied Biochemistry, University of Tsukuba, Ibaraki 305, Japan

(Accepted February 9, 1998) but GR activity was decreased. The results suggested that $\mathrm{Mg}^{2+}$ deficiency enhances the antioxidative enzymes in plants. Foliar application of paraquat and oxyfluorfen, active oxygen-generating herbicides, to kidney bean plants caused herbicidal damage. However, the chlorosis and water loss of kidney bean by the herbicides were much lower in $\mathrm{Mg}^{2+}$ deficient leaves than in $\mathrm{Mg}^{2+}$-sufficient ones. The data demonstrated that $\mathrm{Mg}^{2+}$-deficient kidney bean plants became highly tolerant to paraquat and oxyfluorfen injury.

Key words: $\mathrm{Mg}^{2+}$ deficiency, antioxidative enzymes, paraquat, oxyfluorfen

\section{Introduction}

Oxygen molecules in the atmosphere are relatively stable, but when they come into contact with the metabolic pathway they can be trandformed into active forms such as superoxide $\left(\mathrm{O}_{2}^{-}\right)$, hydrogen peroxide $\left(\mathrm{H}_{2} \mathrm{O}_{2}\right)$, hydroxy radical $(\cdot \mathrm{OH})$ and singlet oxygen $\left({ }^{1} \mathrm{O}_{2}\right)^{26)}$. These oxygen species are often called active oxygen. They interact with a wide range of biological molecules and cause oxidative damage. The plant response under extreme enviromental conditions is known to be associated with free radicals or oxidative damage. These conditions are caused by herbicides $^{2,23)}$, air pollutants ${ }^{22)}$, toxic metals ${ }^{6)}$, temperature extremes ${ }^{16)}$, salt stress ${ }^{26)}$ and so 
forth. Plant species have acquired a kind of defensive ability to overcome oxidative stress in the course of evolution. Their defense mechanisms contain antioxidants such as Vitamin C, E, carotenoids and glutathione, and antioxidative enzymes such as superoxide dismutase (SOD), ascorbate peroxidase (AP), glutathione reductase (GR) and catalase $e^{9,26)}$

Magnesium is a main unit of chlorophyll. It also is a cofactor of chloroplast ribosome (a $70 \mathrm{~S}$ ribosome) that is responsible for biosynthesis of large subunits of ribulose 1, 5 -bisphosphate (RUBP) carboxylase ${ }^{13)}$. In $\mathrm{Mg}^{2+}$-deficient chloroplasts, $\mathrm{CO}_{2}$ fixation can be impaired by the inhibition of biosynthesis of RUBP carboxylase. This may lead to the generation of harmful active oxygen species by photosystem I and II.

It is known that paraquat, a bipyridylium herbicide, and oxyfluorfen, a photobleaching diphenyl ether herbicide, injure plants by photogeneration of toxic oxygen species ${ }^{1,8}$. The active oxygen species formed by paraquat $^{7)}$ and oxyfluorfen ${ }^{8)}$ are potentially capable of peroxidizing cellular components such as chlorophyll and membrane lipids; however, plant species vary in their tolerance to paraquat $^{5,25)}$ and oxyfluorfen ${ }^{19)}$, As plants have an antioxidative system composed of antioxidants and enzymes responsible for quenching the radicals and maintaining a protective redox state, different levels of antioxidants $^{10,19)}$ or protective enzyme activities ${ }^{14,21)}$ among the species could be possible be factors determining their tolerance to the herbicides.

In this paper, as part of our attempt to understand the process of acclimation of plants to environmental stress, we studied the responses of $\mathrm{O}_{2}^{-}$and $\mathrm{H}_{2} \mathrm{O}_{2}$ scavenging enzymes in cucumber and kidney bean plants grown with an insufficient $\mathrm{Mg}^{2+}$ supply.
Tolerance against paraquat and oxyfluorfen toxicity was also studied in kidney bean.

\section{Materials and Methods}

\section{Plant growth}

Cucumber (Cucumis sativus L.) and kidney bean (Phaseolus vulgaris L.) were grown in a controlled environmental chamber (light/ dark regimes $14 / 10 \mathrm{~h}$ at $27 / 22^{\circ} \mathrm{C}$, relative humidity $65-75 \%$ ) with light intensity of 250 $\mu \mathrm{Em}^{-2} \mathrm{~s}^{-1}$ provided by fluorescent and incandescent lamps. Seeds were germinatied in vermiculite saturated with water. After 7 days, the seedlings were transferred to a nutrient solution. The nutrient solution was made by a slightly modified composition of that described by Cakmak and Marschner ${ }^{4}$. Composition of the nutrient solution used was as follows: $0.88 \times 10^{-3} \mathrm{M} \mathrm{K}_{2} \mathrm{SO}_{4} ; 2 \times 10^{-3} \mathrm{M}$ $\mathrm{KCl} ; 1 \times 10^{-5} \mathrm{M} \mathrm{H}_{3} \mathrm{BO}_{3} ; 4 \times 10^{-5} \mathrm{M}$ FeEDTA ; $1 \times 10^{-6} \mathrm{M} \mathrm{MnSO}_{4} ; 1 \times 10^{-6} \mathrm{M} \mathrm{ZnSO}_{4} ; 1 \times 10^{-7}$ $\mathrm{M} \mathrm{CuSO}_{4} ; 1 \times 10^{-8} \mathrm{M}\left(\mathrm{NH}_{4}\right)_{6} \mathrm{MoO}_{24} ; 1 \times 10^{-3}$ $\mathrm{M} \mathrm{Mg}^{2+}$ (sufficient condition) or $7 \times 10^{-6} \mathrm{M}$ $\mathrm{Mg}^{2+}$ (deficient condition) as $\mathrm{MgSO}_{4}$. Plants were harvested 5 to 11 days after transfer to the nutrient solution. At harvest, primary leaves were separated and dried at $105^{\circ} \mathrm{C}$ for $24 \mathrm{hr}$ to determine $\mathrm{Mg}^{2+}$ concentration. For analysis of enzyme activities and chlorophyll contents, the primary leaves were harvested and stored at $-70^{\circ} \mathrm{C}$. For paraquat and oxyfluorfen treatment, kidney bean plants grown for 11 days in nutrient solution with deficient and sufficient $\mathrm{Mg}^{2+}$ supply were used.

\section{Enzyme determinations}

About $0.5 \mathrm{~g}$ of leaf material without the main midrib was ground with liquid nitrogen and homogenized with $5 \mathrm{ml}$ of $100 \mathrm{mM}$ potassium phosphate buffer ( $\mathrm{pH} 7.0$ ) containing $5 \mathrm{mM}$ ethylenediaminetetraacetic acid (EDTA), $1 \mathrm{mM}$ ascorbic acid (AsA) and 20\% polyvinylpolypyrrolidone ( $\mathrm{PVP}: \mathrm{w} / \mathrm{v})$ with a 
mortar and pestle ${ }^{19)}$. The homogenate was centrifuged at $12,000 \mathrm{~g}$ for $20 \mathrm{~min}$. The supernatant was used for determination of enzyme activities. All enzyme activities were measured at $25^{\circ} \mathrm{C}$ in a final volume of $1 \mathrm{ml}$ using aliquots of the supernatants $(25-50 \mu \mathrm{l}$ for ascorbate peroxidase (AP) ; $100 \mu \mathrm{l}$ for glutathione reductase (GR) ; and $25-100 \mu 1$ for superoxide dismutase (SOD)).

Activity of AP was measured by monitoring the rate of ascorbate oxidation at $290 \mathrm{~nm}$ $\left(\mathrm{E}=2.8 \mathrm{mM}^{-1} \mathrm{~cm}^{-1}\right)$. The reaction mixture consisted of $50 \mathrm{mM}$ potassium phosphate buffer ( $\mathrm{pH} 7.0$ ), 0.1mM $\mathrm{H}_{2} \mathrm{O}_{2}, 0.5 \mathrm{mM}$ ascorbate, and the enzyme aliquot. Glutathione reductase was assayed according to the method of Foyer and Halliwell ${ }^{11}$ by following the decrease in absorbance at $340 \mathrm{~nm}$ due to NADPH oxidation $\left(E=6.2 \mathrm{mM}^{-1} \mathrm{~cm}^{-1}\right)$. The reaction mixture contained $100 \mathrm{mM}$ potas sium phosphate buffer ( $\mathrm{pH} 7.8$ ), $3 \mathrm{mM} \mathrm{MgCl}_{2}$, $0.5 \mathrm{mM}$ GSSG, $0.2 \mathrm{mM} \mathrm{NADPH}$, and the enzyme aliquot. SOD was measured by the method described by McCord and Fridovich ${ }^{20)}$. Prior to assay, crude enzyme was dialyzed for $24 \mathrm{hr}$ at $2^{\circ} \mathrm{C}$. The assay mixture was comprised of $50 \mathrm{mM}$ potassium phosphate buffer ( $\mathrm{pH} 7.8), 0.1 \mathrm{mM}$ xanthine monosodium salt, $10 \mathrm{mM}$ cytochrome $\mathrm{C}$, and an aliquot of xanthine oxidase (XOD) which caused a 0.04 increment of the absorbance at $550 \mathrm{~nm}$ during $120 \mathrm{sec}$, and the crude enzyme aliquot. One unit of SOD activity was defined the amount of enzyme to required to reduce $50 \%$ of the absorbance which was increased by XOD addition.

\section{Herbicide treatments}

The primary leaves of kidney bean plants were sprayed with $5 \mathrm{ml}$ of 300,600 and $900 \mu \mathrm{M}$ paraquat containing $0.1 \%$ tween 20 or 40,80 and $120 \mu \mathrm{M}$ oxyfluorfen dissolved in $30 \%$ acetone containing $0.2 \%$ tween 20 . After the treatments, surface of the leaves was dried in the dark, and they were then transferred to the growth chamber with light irradiation at $250 \mu \mathrm{Em}^{-2} \mathrm{~S}^{-1}$. Plant injury was determined after 24 hours for paraquat and 48 hours for oxyfluorfen treatment.

\section{Analytical methods}

The $\mathrm{Mg}^{2+}$ concentrations were determined by an inductively coupled plasma (ICP) spectrometer after grinding dried leaves with a mortar and pestle and extracting with $1 \mathrm{~N}$ $\mathrm{HCl}$ for $12 \mathrm{hr}$. Concentrations of chlorophyll $(\mathrm{a}+\mathrm{b})$ were measured after extraction with dimethyl sulfoxide at $60^{\circ} \mathrm{C}$ for $12 \mathrm{hr}$ as described by Hiscox and Israelstam ${ }^{15)}$. Protein concentration was determined by the method of Bradford ${ }^{3)}$.

\section{Results and Discussion}

Sufficient $\mathrm{Mg}^{2+}$ supply significantly increased dry matter production of root and shoots of cucumber and kidney bean plants, however, at the insufficient supply, their dry weight increments were slight (data not shown). $\mathrm{Mg}^{2+}$ concentration in the primary leaves of $\mathrm{Mg}^{2+}$-sufficient plants was increased gradually for a given period (Fig. 1). In the leaves of those $\mathrm{Mg}^{2+}$-deficient, however, the concentration was significantly lower than that of the $\mathrm{Mg}^{2+}$-sufficient condition (only about $1 / 26$ for cucumber and $1 / 23$ for kidney bean plants at 11 days).

Chlorophyll diminution in the primary leaves by $\mathrm{Mg}^{2+}$ deficiency differed between plant species (Fig. 2). Visual injury (data not shown) and reduction of chlorophyll arosed in cucumber plants after 5 days of growth in the nutrient solution with inadequate $(7 \mu \mathrm{M})$ $\mathrm{Mg}^{2+}$ supply. The symptoms appeared more rapidly than in kidney bean. In kidney bean plants, chlorophyll content was little affected by $\mathrm{Mg}^{2+}$ deficiency (Fig. 2(B)), and inter- 

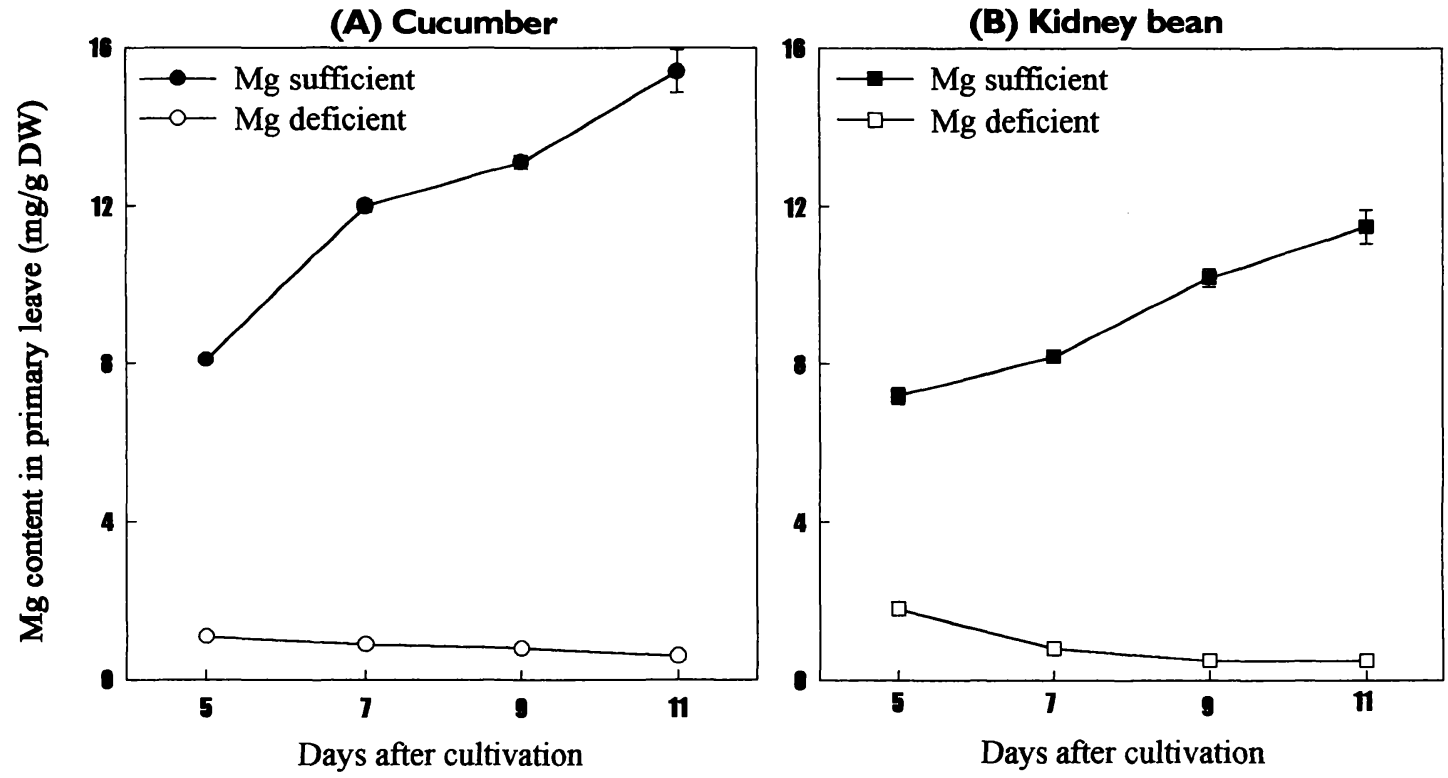

Fig. 1. Concentration of $\mathrm{Mg}$ in the primary leaves of cucumber and kidney bean plants grown in nutrient solutions with sufficient $(1000 \mu \mathrm{M})$ and deficient $(7 \mu \mathrm{M}) \mathrm{Mg}$ supply. Each data point represents the mean of three replicates. Bars indicate $\mathrm{SE}$.

(A) Cucumber

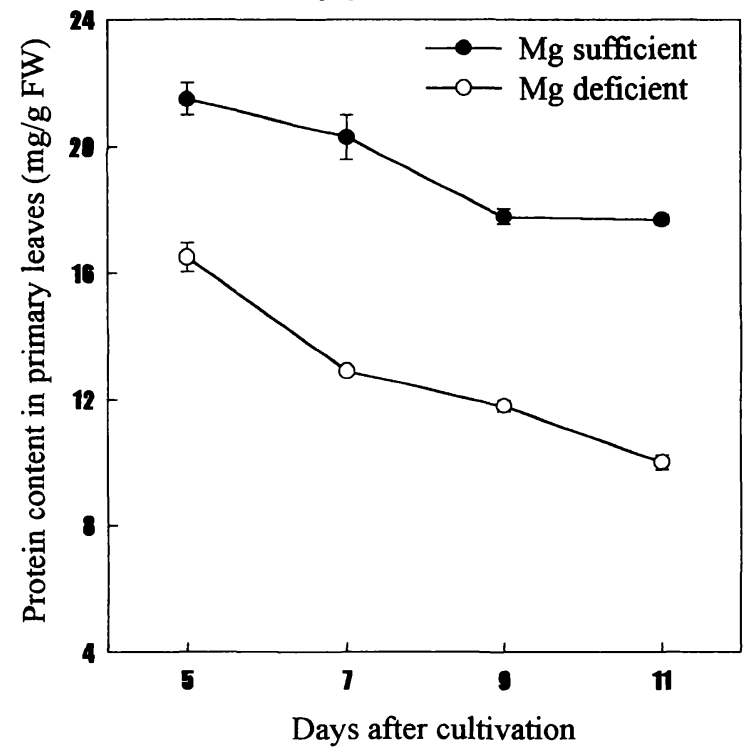

(B) Kidney bean

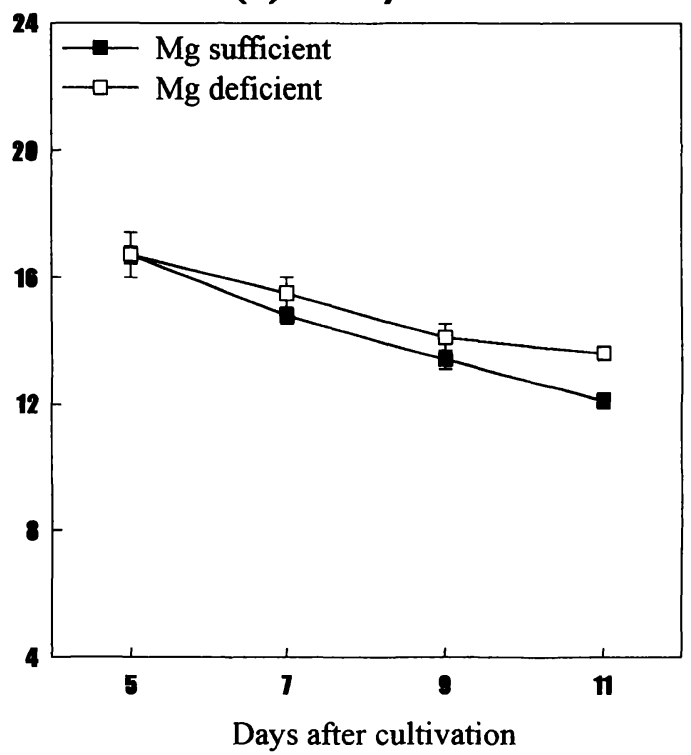

Fig. 2. Concentration of chlorophyll in the primary leaves of cucumber and kidney bean plants grown in nutrient solutions with sufficient $(1000 \mu \mathrm{M})$ and deficient $(7 \mu \mathrm{M}) \mathrm{Mg}$ supply. Each data point represents the mean of three replicates. Bars indicate SE. 
veinal chlorosis and rugged or rugous surface of the primary leaf appeared with time (data not shown). Regardless of $\mathrm{Mg}^{2+}$ status, protein concentration of the tested plant species decreased with time (Fig. 3). The protein content was remarkably lower in $\mathrm{Mg}^{2+}$-deficient cucumber leaves than in $\mathrm{Mg}^{2+}$-sufficient ones (Fig. 3(A)): the concentration was $77 \%$ after 5 days and $57 \%$ after 11 days compared to leaves grown in nutrient solution with $\mathrm{Mg}^{2+}$ sufficient supply. The protein content of kidney bean plants, however, was not reduced by $\mathrm{Mg}^{2+}$ deficiency (Fig. 3(B)).

Effects of $\mathrm{Mg}^{2+}$ supply on antioxidative enzyme activities of cucumber and kidney bean plants are shown in Fig. 4. The activities of antioxidative enzymes in the leaves of both plant species except GR in kidney bean plants increased greatly with time in $\mathrm{Mg}^{2+}$ deficient condition. After 11 days, AP, GR and SOD activities in cucumber were 3.6, 2.8 and 3.9 times higher in leaves of $\mathrm{Mg}^{2+}$-defi- cient than $\mathrm{Mg}^{2+}$-sufficient plants, respectively. In kidney bean, AP and SOD activities were 3.7 and 2.1 times higher in $\mathrm{Mg}^{2+}$-deficient plants than $\mathrm{Mg}^{2+}$-sufficient plants, respectively. However GR activity of $\mathrm{Mg}^{2+}$ deficient plants was decreased to $62 \%$ compared to that of $\mathrm{Mg}^{2+}$-sufficient leaves.

Since kidney bean showed less chlorosis than cucumber by $\mathrm{Mg}^{2+}$ deficiency, it was used as test plant species to evaluate of herbicidal damage. The extent of chlorosis in the primary leaves clearly indicated that the tolerance of kidney bean plants to paraquat and oxyfluorfen was increased greatly by $\mathrm{Mg}^{2+}$ deficiency (Figs. 5 and 6). After being sprayed with paraquat of oxyfluorfen, $\mathrm{Mg}^{2+}$ sufficient leaves showed intensive chlorosis with increasing herbicide concentration, whereas in $\mathrm{Mg}^{2+}$-deficient leaves, the chlorosis was remarkably diminished (Fig. 5). Toxic oxygen species produced by paraquat ${ }^{1)}$ and oxyfluorfen ${ }^{8)}$ attack unsaturated fatty
(A) Cucumber

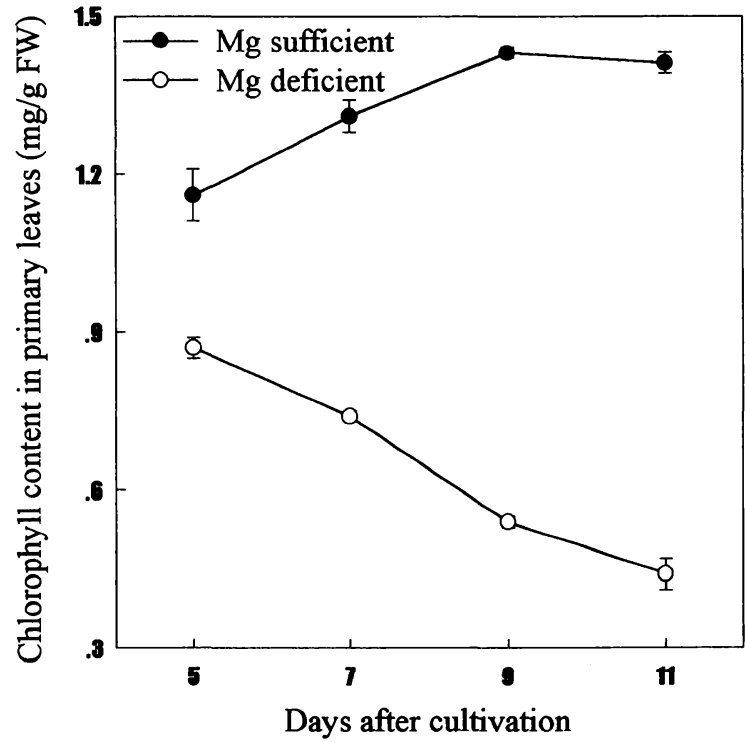

(B) Kidney bean

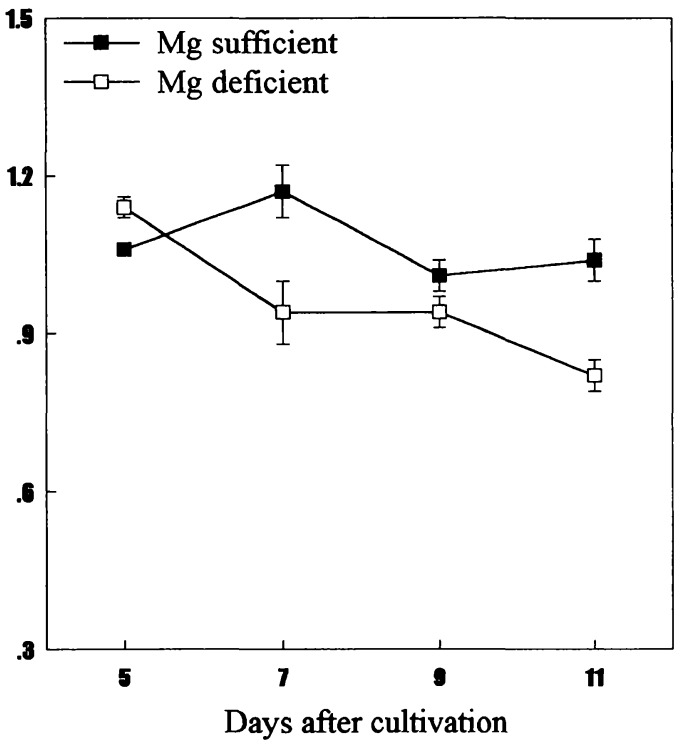

Fig. 3. Changes of protein contents in the primary leaves of cucumber and kidney bean plants grown in nutrient solutions with sufficient $(1000 \mu \mathrm{M})$ and deficient $(7 \mu \mathrm{M}) \mathrm{Mg}$ supply. Each data point represents the mean of three replicates. Bars indicate SE. 


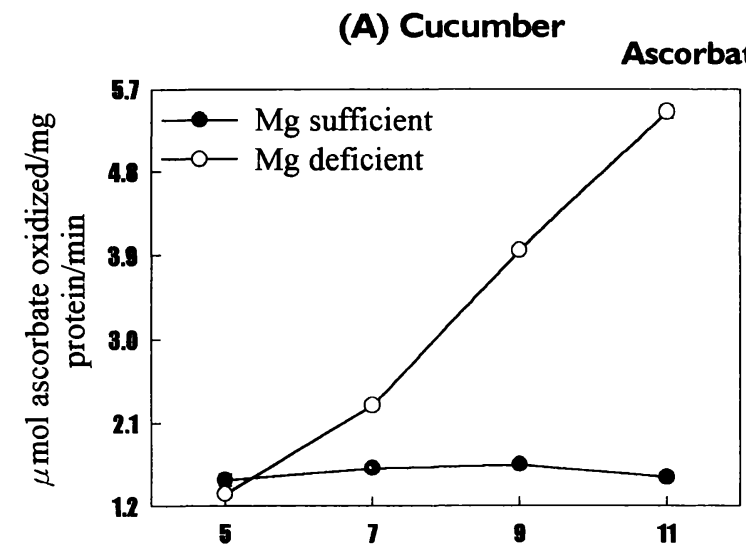

(B) Kidney bean

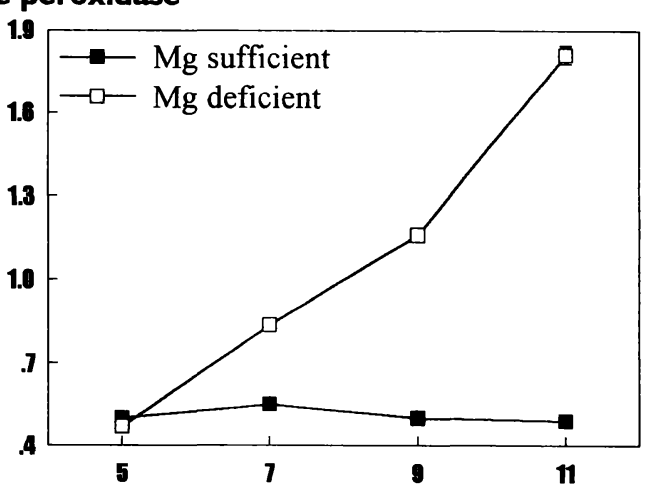

Glutathione reductase
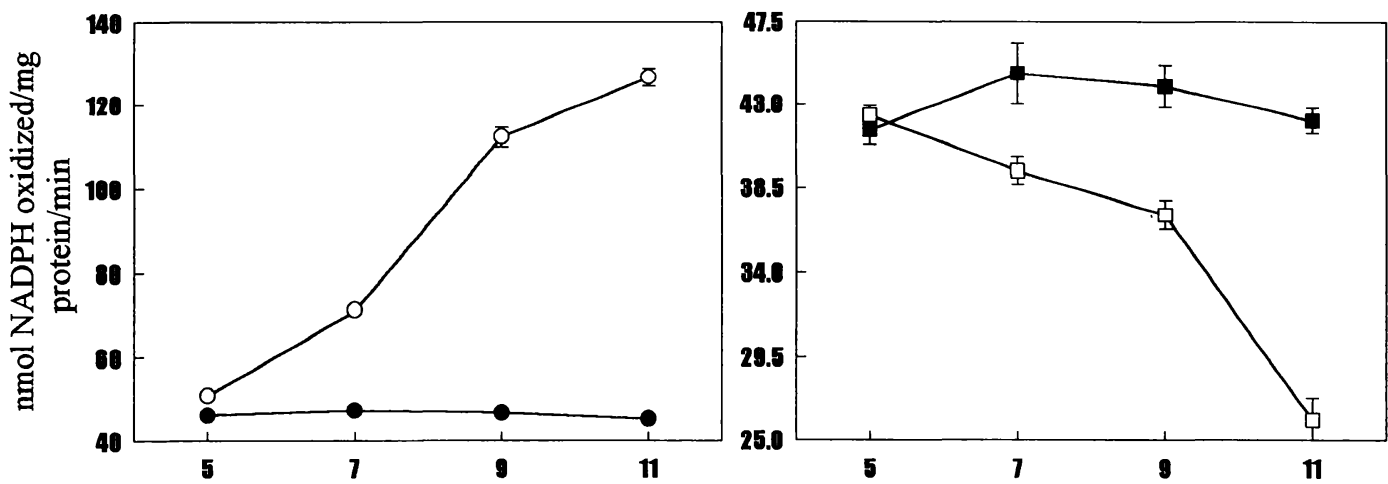

Superoxide dismutase
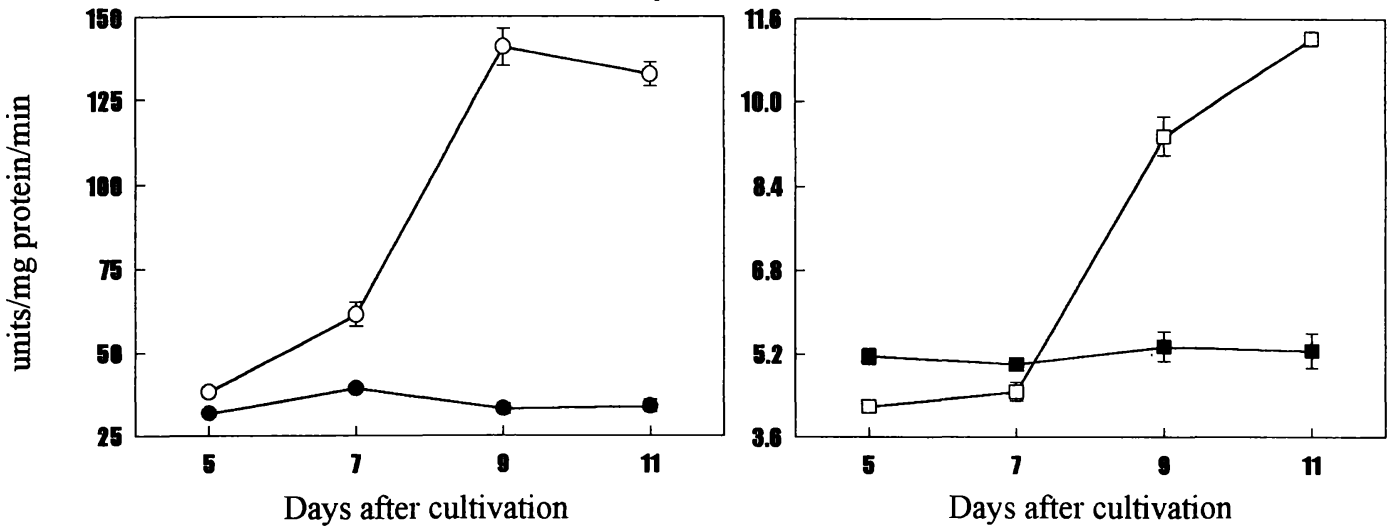

Fig. 4. Activities of ascorbate peroxidase, glutathione reductase and superoxide dismutase in the primary leaves of cucumber and kidney bean plants grown in nutrient solutions with sufficient $(1000 \mu \mathrm{M})$ and deficient $(7 \mu \mathrm{M}) \mathrm{Mg}$ supply. Each data point represents the mean of three replicates. Bars indicate SE.

acids in the plant cell membrane, and initiate a chain reaction of lipid peroxidation ${ }^{5}$. Disintegration of plasmalemma by attacks of the herbicide-generated active oxygen species is accompanied by loss of water ${ }^{18)}$ and electrolyte ${ }^{17)}$ from cells. The phytotoxic effect of paraquat and oxyfluorfen was evaluated by water loss (Fig. 6). Prior to herbicide treat- 


\section{(A) Paraquat \\ $\mathrm{Mg}$ sufficient}
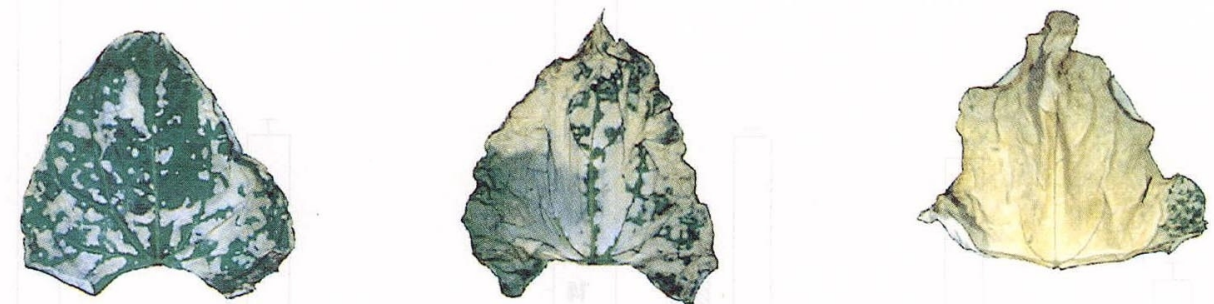

Mg deficient

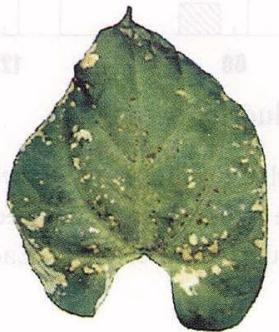

$300 \mu \mathrm{M}$

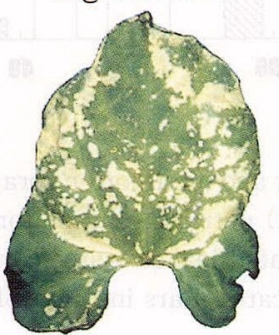

$600 \mu \mathrm{M}$

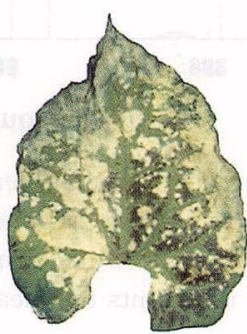

$900 \mu \mathrm{M}$

(B) Oxyfluorfen

$\mathrm{Mg}$ sufficient
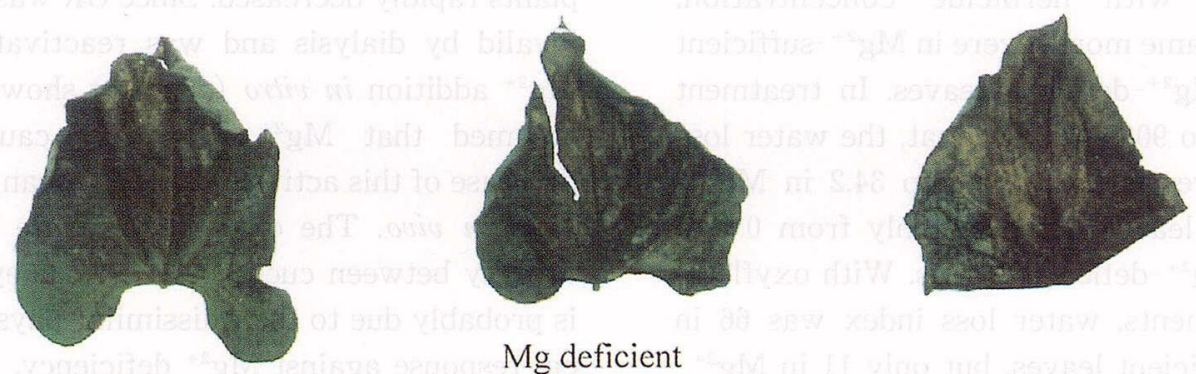

Mg deficient

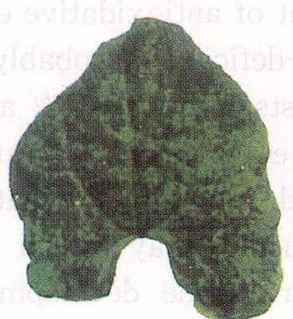

$40 \mu \mathrm{M}$

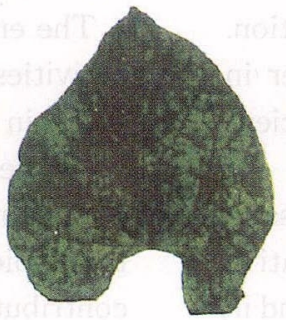

$80 \mu \mathrm{M}$

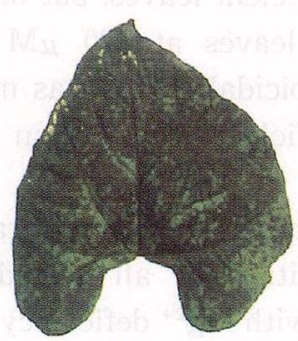

$120 \mu \mathrm{M}$

Fig. 5. Leaf injury by paraquat (A) and oxyfluorfen (B) in kidney bean plants grown in $\mathrm{Mg}$-sufficient and deficient nutrient solutions for 11 days. Paraquat or oxyfluorfen solution was sprayed on primary 11 day old leaves, and the plants were kept under light for 24 or 48 hours, respectively. 

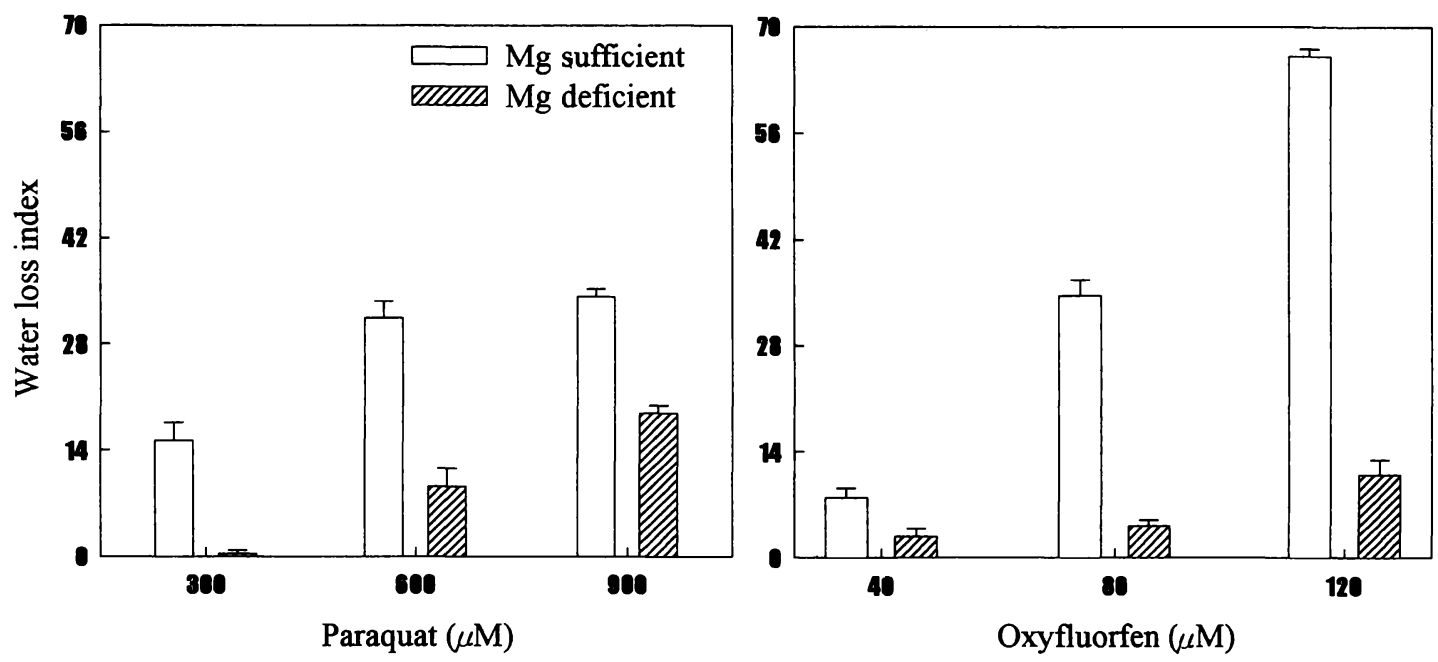

Fig. 6. Water loss of primary leaves by paraquat and oxyfluorfen spray to intact kidney bean plants grown in $\mathrm{Mg}$ -sufficient $(1000 \mu \mathrm{M})$ and deficient $(7 \mu \mathrm{M})$ nutrient solution for 11 days. The indices are calculated by the formula, 100-(water content (\%) of treated leaves/water content (\%) of untreated leaves). Each data point represents the mean of three replicates. Bars indicate SE.

ment, there was no difference in water content between $\mathrm{Mg}^{2+}$-sufficient and $\mathrm{Mg}^{2+}$-deficient plants (data not shown). Water loss increased with herbicide concentration, which became more severe in $\mathrm{Mg}^{2+}$-sufficient than in $\mathrm{Mg}^{2+}$-deficient leaves. In treatment with 300 to $900 \mu \mathrm{M}$ paraquat, the water loss index increased from 15.3 to 34.2 in $\mathrm{Mg}^{2+}$ sufficient leaves, although only from 0.4 to 18.9 in $\mathrm{Mg}^{2+}$-deficient leaves. With oxyfluorfen treatments, water loss index was 66 in $\mathrm{Mg}^{2+}$-sufficient leaves, but only 11 in $\mathrm{Mg}^{2+}$ deficient leaves at $120 \mu \mathrm{M}$ concentration. Thus herbicidal injury was much greater in $\mathrm{Mg}^{2+}$-sufficient leaves than $\mathrm{Mg}^{2+}$-deficient leaves.

In cucumber, there was a rapid increase in the activities of all tested antioxidative enzymes with $\mathrm{Mg}^{2+}$ deficiency (Fig. 4), and in kidney bean, the activities of AP and SOD increased with $\mathrm{Mg}^{2+}$ deficiency (Fig. 4). However, the activity of $\mathrm{GR}$ in $\mathrm{Mg}^{2+}$-deficient kidney bean plants decreased with time. Although Cakmak and Marscher ${ }^{4)}$ reported that GR activity of kidney bean plants was enhanced by $\mathrm{Mg}^{2+}$ deficiency, our data indicated that the enzyme activity of those plants rapidly decreased. Since GR was made invalid by dialysis and was reactivated by $\mathrm{Mg}^{2+}$ addition in vitro (data not shown), we assumed that $\mathrm{Mg}^{2+}$ deficiency caused a decrease of this activity in kidney bean plants even in vivo. The opposite response of GR activity between cucumber and kidney bean is probably due to their dissimilar physiological response against $\mathrm{Mg}^{2+}$ deficiency.

The enhancement of antioxidative enzyme activities by $\mathrm{Mg}^{2+}$-deficiency probably takes place in chloroplasts where $\mathrm{SOD}^{16)}$ and the $\mathrm{H}_{2} \mathrm{O}_{2}$ detoxifying enzymic cycle ${ }^{24)}$ are predominantly located. The photooxidation of thylakoid constituents may be a major contributing factor in the development of chlorosis. Furthermore, the dissimilarity of plant response between species against $\mathrm{Mg}^{2+}$ deficiency may be related to constitutive differences for generation or detoxification of harmful $\mathrm{O}_{2}$ species in the chloroplasts. 
The results presented here show that paraquat and oxyfluorfen toxicity in kidney bean leaves was greatly affected by the nutritional status of $\mathrm{Mg}^{2+}$ (Figs. 5, 6). The activites of antioxidative enzymes in kidney bean plants became more distinct with progressing $\mathrm{Mg}^{2+}$ deficiency except for GR, and the plant tolerance to paraquat and oxyfluorfen was increased greatly compared to $\mathrm{Mg}^{2+}$ sufficiency. The relationship between enhanced antioxidative capacity and tolerance to the herbicides suggests that development of the tolerance is causally related to the elevated detoxification capacity in the leaves. Environmental stress which generates active oxygen species is known to improve the activity of antioxidative enzymes, and to enhance their tolerance to active oxygen generating herbicides, as reported elsewhere ${ }^{12,21)}$. Therefore, kidney bean with $\mathrm{Mg}^{2+}$ deficiency may be more tolerant to other $\mathrm{O}_{2}$ activating stress factors.

\section{References}

1) Asada, K., M. Takahashi and Y. Nakano. 1977. Formation of active oxygen and its fate in chloroplasts. In "Biochemical and Medical Aspects of Active Oxygen" ed. by O. Hayashi. K. Asada. Japan Scientific Soci. Press, Tokyo, pp. $45-63$.

2) Babbs. C. F., J. M. Pham and R. C. Coolbaugh. 1989. Lethal hydroxyl radical production in paraquat-treated plants. Plant Physiol. 90: 1267 -1270 .

3) Bradford, M. M. 1976. A rapid and sensitive method for the quantitation of microgram quantites of protein utilizing the principle of protein-dye binding. Anal. Biochem. 72: 248255.

4 ) Cakmak, I. and H. Marschner. 1992. Magnesium deficiency and high light intensity enhance activities of superoxide dismutase, ascorbate peroxidase, and glutathione reductase in bean leaves. Plant Physiol. 98: 1222-1227.

5 ) Cobb. A. 1992. Herbicides and Plant Physiolgy.
T. J. Press (Padstiw). Ltd. Padstow, Cornwall. pp. 36-79.

6) De Vos, C. H. R., M. J. Vonk, R. Vooijs and H. Schat. 1992. Glutathione depletion due to copper - induced phytochelatin synthesis causes oxidative stress in Silene cucubalus. Plant Physiol. 98: 853-858.

7 ) Dodge, A. D. 1991. Herbicides interacting with photosystem I. In "Target Sites for Herbicide Action" ed. by R. C. Kirkwood. Plenum Press. New York. pp. 12-14.

$8)$ Duke, S. O., J. M. Becerril. T. D. Sherman and H. Matsumoto. 1990. Photosensitizing Porphyrins as Herbicides Am. Chem. Soc. Symp. Ser. 449: $371-386$.

9) Elstner. E. F. 1982. Oxygen activation and oxygen toxicity. Ann. Rev. Plant Physiol. 33: 73-96.

10) Finckh, B. F. and K. J. Kunert. 1985. Vitamins $C$ and $\mathrm{E}:$ An antioxidative system against herbicide-induced lipid peroxidation in higher plants. J. Agric. Food Chem 33: 574-577.

11) Foyer, C. H. and B. Halliwell. 1976. The presence of glutathione and glutathione reductase in chloroplasts : a proposed role in ascorbic acid metabolism. Planta 133: 21-25.

12) Gillham. D. J. and A. D. Dodge. 1986. Hydrogen -peroxide-scavenging systems within pea chloroplasts. A quantitative study. Planta 167: 246251.

13) Goodwin. T. W. 1983. Introduction to Plant Biochemistry, Second Edition. Pergamon Press. New York. pp. 394-399.

14) Harper. D. B. and B. M. R. Harvey. 1978. Mechanism of paraquat tolerance in perennial ryegrass. II. Role of superoxide dismutase. catalase and peroxidase. Plant, Cell and Environ. 1: 211-215.

15) Hiscox, J. D. and G. F. Isarelstam. 1979. A method for the extraction of chlorophyll from leaf tissue without maceration. Can. J. Bot. 57: 1332-1334.

16) Kendall, E. J. and B. D. McKersie. 1989. Free radical and freezing injury to cell membranes of winter wheat. Physiol. Plant. 76: 86-94.

17) Kojima, S., H. Matsumoto and K. Ishizuka. 1991. Protophyrin IX accumulation in Lemna paucicostata Hegelm. caused by diphenyl ether herbicides and their herbicidal activity. Weed 
Res. (Tokyo) 36: 318.

18) Lee, J. J., H. Matsumoto and K. Ishizuka. 1992. Light Involvement in Oxyfluorfen-Induced Protoporphyrin IX Accumulation in Several Species of Intact Plants. Pest. Biochem. Physiol., 44: 119-125.

19) Matsumoto. H., J. J. Lee and K. Ishizuka. 1994. Variation in Crop Response to Protoporphyrinogen Oxidase Inhibitors. Am. Chem. Soc. Symp. Ser. 559: 120-132.

20) McCord, J. M. and I. Fridovich. 1969. Superoxide dismutase. J. Biol. Chem. 244: 6049-6055.

21) Mehlhorn, H. 1990. Ethylene-promoted ascorbate peroxidase activity protects plants against hydrogen peroxide. ozone and paraquat. Plant. Cell and Environ. 13: 971-976.

22) Mehlhorn. H., D. A. Cottam. P. W. Lucas and A. R. Wellburn. 1987. Induction of ascorbate perox- idase and glutathione reductase activities by interactions of mixtures of air pollutants. Free Radical Research Commun. 3: 193-197.

23) Orr, G. L. and F. D. Hess. 1982. Mechanism of action of the diphenylether herbicide acifuorfen -methyl in excised cucumber (Cucumis sativa L.) cotyledons. Plant Physiol. 69: 502-507.

24) Robinson, J. M. 1988. Does $\mathrm{O}_{2}$ photoreduction occur within chloroplasts in vivo. Physiol. Plant. 72: 666-680.

25) Shaaltiel, Y., A. Glazer. P. F. Bocion and J. Gressel. 1988. Cross tolerance to herbical and environmental oxidants of plant biotypes tolerant to paraquat, sulfur dioxide and ozone. Pest. Biochem. Physiol. 31: 13-23.

26) Smirnoff. N. 1993. The role of active oxygen in the response of plants to water deficit and desiccation. Tansley Review No. 52. 125: 27-58.

\section{マグネシウム欠乏が抗酸化酵素活性誘導と} 活性酸素生成型除草凪に対する 抵抗性増加に及ぼす影響

李増周*・金秉徹 $*$ 松本 宏 ${ }^{* *} \cdot$ 臼井健二**

\section{摘 要}

有害な活性酸素種を生成する環境ストレスに対す る植物の適応過程を把握するための一環として, キ ユウリとツルナシインゲンマメをマグネシウム $\left(\mathrm{Mg}^{2+}\right)$ 欠乏の水耕液で栽培した時に発現するクロロフィル 含量と $\mathrm{Mg}^{2+}$ 濃度の変化, 抗酸化酵素の活性変動など を調べた。また, ツルナシインゲンマメの活性酸素 生成型除草剤パラコートとオキシフルオルフェンに 対する抵抗性に及ほす $\mathrm{Mg}^{2+}$ 欠乏の影響についても検 討した。

$\mathrm{Mg}^{2+}$ が充分に供給された水耕液で栽培されたキュ ウリとツルナシインゲンマメでは初生葉の $\mathrm{Mg}^{2+}$ 含量 が増加したが, $\mathrm{Mg}^{2+}$ 欠乏で栽培された植物では影著

\footnotetext{
* 韓国慶尚大学農科大学生物学科
}

**筑波大学応用生物化学系
に滅少した(Fig. 1)。 $\mathrm{Mg}^{2+}$ 欠乏は, ツルナシインゲ ンマメよりキュウリにおいて,クロロフィルおよび 蛋白質含量を著しく隇少させた (Figs. 2，3)。また， $\mathrm{Mg}^{2+}$ の欠乏によってキュウリではアスコルビン酸ペ ルオキシダーゼ (AP), グルタチオンレダクターゼ (GR)ならびにスーパーオキシドジスムターゼ(SOD) が,ツルナシインゲンマメでは AP および SOD の活 性が著しく高くなることが判明した（Fig. 4)。

ツルナシインゲンマメは活性酸素を生成する作用 があるパラコートとオキシフルオルフェンに対し感 受性を示したが, $\mathrm{Mg}^{2+}$ 欠乏条件下で育成した植物は クロロシスと水分損失率が少なく, 両薬片により抵 抗性になることが明らかになった (Figs. 5，6)。こ れらの結果から, $\mathrm{Mg}^{2+}$ の欠乏が供試植物種において, 有害な活性酸素種を消去する作用がある抗酸化酵素 活性を促進する作用があることが示され，また，ツ ルナシインゲンマメでは AP と SOD 活性の増加が, 活性酸素種を生成する除草剤に対する植物の抵抗性 を高めた一つの原因になっているものと推察される。

キーワード: $\mathrm{Mg}^{2+}$ 欠乏, 抗酸化酵素, パラコート,オ キシフルオルフェン 